\title{
The Insertion of the Ceara Textile Sector in a Circular Economy: A View of Sustainability Relations
}

\author{
Milton Jarbas Rodrigues Chagas ${ }^{1}$ (), Armando de Azevedo Caldeira-Pires ${ }^{2}$ (]) \\ ${ }^{1}$ Center for applied social sciences, Federal University of Cariri (UFCA), Juazeiro do Norte, Brazil \\ ${ }^{2}$ Technology College, University of Brasília (UnB), Brasília, Brazil \\ Email: milton.rodrigues@ufca.edu.br
}

How to cite this paper: Chagas, M.J.R. and de Azevedo Caldeira-Pires, A. (2021) The Insertion of the Ceara Textile Sector in a Circular Economy: A View of Sustainability Relations. Journal of Textile Science and Technology, 7, 101-111.

https://doi.org/10.4236/jtst.2021.73009

Received: April 24, 2021

Accepted: July 23, 2021

Published: July 26, 2021

Copyright ( $) 2021$ by author(s) and Scientific Research Publishing Inc. This work is licensed under the Creative Commons Attribution International License (CC BY 4.0).

http://creativecommons.org/licenses/by/4.0/

\begin{abstract}
This article aims to analyze how the textile industry in Ceará relates to other economic sectors, in the context of a Circular Economy. A multi-case study was carried out with semi-structured interviews with the managers of the textile industries in Ceará registered with the Union of the textile industry in Ceará, in addition to a survey of articles in the Scopus database, considering the keywords "Circular Economy" and "Textile". The managers interviewed reported that they practice sustainability actions that relate to the concepts of Circular Economy, even though they do not have knowledge on the topic.
\end{abstract}

\section{Keywords}

Circular Economy, Textile Sector, Ceará

\section{Introduction}

Over the decades, studies have been carried out and public policies have been proposed and adopted with a focus on actions aimed at reducing environmental impacts caused by the production process [1]. In this sense, agendas were adopted by different countries, aiming to combine economic development with the maintenance of natural capital.

Among the global initiatives, aimed at sustainable development, are the first World Circular Economy Forum, held in June 2017, in Finland, with the participation of more than 1500 specialists on the theme, including company directors, politicians and actors in the establishment of public policies in 90 countries, discussing a detailed action plan to adopt the new model of Circular Economy and the Fourth UN Environment Assembly, in Nairobi, Kenya, on March 15, 
2019, when ministers from more than 170 countries adopted a plan that calls for accelerating the shift to sustainable development models.

In 2015, aiming to adopt a sustainable development agenda and a global agreement on climate change, the United Nations launched the Sustainable Development Goals (SDGs), comprising 17 objectives and 169 goals to be achieved by 2030 [2].

The objectives and goals established in the SDGs guide countries in the development of joint actions, which include sustainable development, in its different dimensions: economic, social, environmental, culture, space, psychological and national and international politics, as a focus [3].

Among the 17 objectives listed, those of numbers 8 (Promote sustainable, inclusive and sustainable economic growth, full and productive employment, and decent work for all), and 9 (Build resilient infrastructure, promote inclusive and sustainable industrialization and foster innovation) and 12 (Sustainable consumption and production) are related to each other, as they focus on establishing sustainable industrial processes with the promotion of sustained economic growth with innovation.

Circular business models facilitate the flow of goods and services and, at the same time, insert elements in the production process that were not appropriate to cost, such as mass and energy flows. Circular thinking provides sustainable planning of products, returning to the system after use. The benefits of circular businesses can be financial, social and environmental [4].

[5] argues that the Circular Economy aims to optimize the use of virgin resources and reduce pollution and waste at each stage of the production process, as far as possible and desirable. The constant adaptation, regeneration, recreation and innovation in terms of sustainable practices generate concepts that aggregate and congregate elements that have the potential to produce substantive effects on sustainability [6].

With the growing concern with environmental and social sustainability, the consumption and pollution of energy and water, the scarcity of natural resources and the emission of greenhouse gases, the textile industry, which generates a substantial environmental footprint since cultivation, fabric manufacture, even the disposal of items in a post-consumer landfill, is facing enormous environmental and resource challenges [7].

The garment industry earns, globally, about $\$ 1.3$ trillion and employs more than 300 million people along the value chain, representing more than $60 \%$ of the total textiles used and is expected to continue to grow. Cotton production alone accounts for almost 7\% of all employment in some low-income countries (Benin, Cameroon, Burkina Faso, Egypt, Chad) [1].

The globalization of the textile system has resulted in an uneven distribution of environmental consequences. It is observed that developing countries, producers of most textiles and clothing, bear the burden for developed countries, consumers of products [8]. 
The Northeast is the second largest region in textile production in Brazil, with Ceará being the state with the largest number of municipalities involved in this activity. The increase in the export of its products and the launch of creations make it a great dynamic center of fashion.

Despite having more than 120 years of history in the textile industry sector, the recent growth in the consumption power of the Northeastern population (and, more specifically, Ceará) is decisive for this scenario. As strengths pointed out in the textile industry of the State of Ceará there are job creation (involving more than 200 thousand people in the region); development of the local market; practically exclusive dedication to the sector; pulverized production, that is, from several producers; contribution to the reduction of social and economic inequalities in the region and construction of a potential area for clients from other regions [9].

Ceará accounts for the $11^{\text {th }}$ economy in the country and for the $3^{\text {rd }}$ in the Northeast. Ceará's GDP comprises $2.1 \%$ of Brazilian GDP and $15.1 \%$ of Northeastern GDP. Its economy is sustained, mainly, in the activities related to Services (76.1\%), followed by the activities of Industry (19.2\%) and Agriculture, which participates with $4.7 \%$ [10].

Main segment of the Ceará industry, the transformation registered a growth of $3.44 \%$ over the same months of the previous year. In the period, the growth is explained by the increase in production in activities that were positively affected by the expansion of the characteristic demand at the end of the year, with emphasis on Clothing and apparel (18.3\%), Beverages (9.5\%) and Food (5.1\%) [11].

According to the Brazilian Association of the Textile and Clothing Industry (ABIT, 2018), in Brazil, the textile sector represents $16.7 \%$ of jobs and $5.7 \%$ of the turnover of the Manufacturing Industry. The State of Ceará, in 2017, occupied the $5^{\text {th }}$ position in the national textile production, generating around 60 thousand jobs directly, bringing together the local production chain.

In view of the relevance of the Ceará textile sector and because no studies were investigated to investigate how this branch of activity relates to other sectors in the context of Circular Economy, this article aims to answer the following research question: how the Ceará textile industry does it relate to other economic sectors, in a context of Circular Economy?

The Scopus database was initially searched for articles whose theme was Circular Economy applied to the textile industry, using as keywords: "Circular Economy" and "textile *", delimiting only in articles in all languages, published until the year 2020. The search returned 99 articles, which were read the titles and abstracts to check if the words "Circular Economy" and "textile *" appeared together, of that amount 63 articles remained. The objective was to identify the studies that carried out empirical research carried out in textile industries and their purposes.

Through a multi-case study, resulting from semi-structured interviews conducted with managers from two textile industries in Ceará registered with Sin- 
ditêxtil, in addition to the analysis of the Input-Product Matrix and the Table of Resources and Uses of the State of Ceará, made available by IPECE (2017), we sought to analyze how the textile industry in Ceará relates to other economic sectors, in the context of a Circular Economy.

With the mapping of relations between sectors, it is possible to identify the path taken by goods, in addition to proposing public policies and systematized actions with the integrated participation of society, the government and the productive industrial sector, which lead to a scenario of Circular Economy.

\section{Use of Textile Waste in Other Industries}

The importance of reuse and recycling in the future improvement of the Circular Economy. In this way, the attention and interest of the textile industry in reuse and recycling is increasing rapidly [1] [7].

Figure 1 shows examples of waste applications from the textile industry in other types of industries and products. These examples make it possible to rethink the circularity of the textile product and the emitted waste.

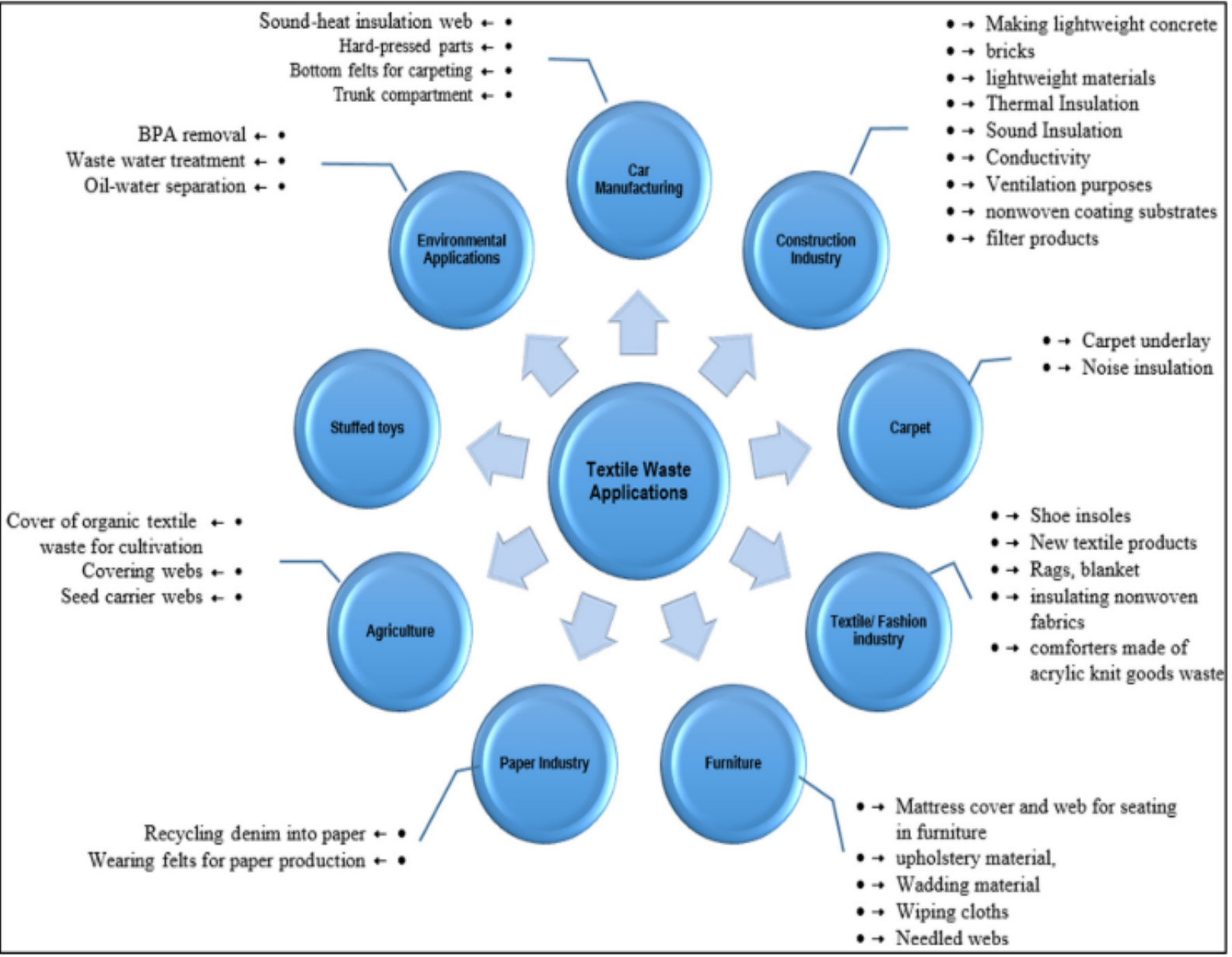

Source: From reference [7] (p.8).

Figure 1. Applications for recycled textile waste in different industries. 
Among the applications for recycled textile products or waste from the textile industry, the following stand out:

- Construction industry: use of fabric residues and residues of this residue as thermal and acoustic insulation, ventilation, conductivity, manufacture of light materials, concrete and bricks;

- Environmental applications: use of cotton waste as a sustainable catalyst, water treatment, pollution remediation and removal of Bisphenol A (BPA) in wastewater;

- Paper industry: use of plastic waste to use felts for paper production and the use of recycled denim for papermaking;

- Textile and fashion industry: Use of textile waste by major fashion and clothing brands for the production of new textile products;

- Carpet industry: use of textile waste such as sound insulation and reinforcement of carpets;

- Automobile industry: Use of recycled textile waste as an acoustic and thermal insulation web, making hard-pressed pieces for seat linings, floors and bottom felts for carpets;

- Agricultural industry: Use of textile waste as a covering layer of the crop surface and recycled fabric used as a covering web and seed carrier;

- Furniture industry: Recycled textile waste used in the manufacture of mattress cover, upholstery material, filling material and needled webs;

- Toys: Recycled textile waste can be used to make soft toys.

Note the possibility of reusing textile waste or recycled textile products in different sectors and for different uses. With this, it is possible to understand the need to map the relations between the textile sector and other sectors located in different locations, aiming to propose sustainable actions aimed at the Circular Economy.

Brazil is currently the fifth largest textile producer in the world, with an emphasis on industrial hubs located in Agreste Pernambucano, in Ceará, in the Itajaí Valley/SC, and in Americana/SP [9]. The share of the manufacturing industry in the Brazilian GDP, according to a CNI report (2019), corresponded to $11.3 \%$ in 2018 .

\section{Strategies Adopted for the Insertion of Industrial Sectors in Circular Economy Scenarios}

In view of the concern with making business models more circular, some organizations are conducting studies and issuing technical reports that contain projections and scenarios, especially with regard to the industrial sector, in the context of Circular Economy. The data indicate which sustainable actions and policies must be taken by each actor involved, be it government, industrial sector and society, in order to achieve the objective of a Circular Economy.

The Ellen MacArthur Foundation, in 2017, launched the report called: "A New textiles economy: Redesigning fashion's future”, which describes a vision 
for a good functioning of the industrial system, providing long-term benefits. This document lists some negative points that justify the planning and execution of sustainable actions as soon as possible:

1) The way the clothes are designed, produced and used has disadvantages in terms of not reusing them;

2) The textile system operates in an almost completely linear manner, that is, with the use of large amounts of non-renewable energy;

3) Resources extracted to produce clothes, which are often used for only a short period, after which the materials are sent mainly to landfills or incinerated;

4) More than $\$ 500$ billion is lost each year due to underutilized clothing and a lack of recycling;

5) The model has numerous negative environmental and social impacts, such as total greenhouse gas emissions from textile production, dangerous substances affect the health of textile workers and, when washed, some clothes release plastic microfibers, of which about half million tonnes a year contribute to ocean pollution.

In Brazil, the reports of the National Confederation of Industry (CNI) and the Brazilian Association of the Textile Industry (ABIT) stand out. In 2018, ABIT launches the report entitled: "The Power of Fashion: Scenarios, Challenges and Perspectives", presenting the profile of the global and Brazilian textile industry; the internal and external relations of the Brazilian textile production and the projections of scenarios for the coming years. The main actions on the agenda are strengthening of clothing through the qualification of personnel and investment in innovation; implementation of tax and financing management policies; defense of the expansion of commercial relations and increase of productivity and competitiveness with sustainable actions.

In 2019, the European Commission prepared the "Report from the Commission to the European Parliament, The Council, The European Economic and Social Committee and the Committee of the Regions on the implementation of the Circular Economy Action Plan." The report presented indicators related to the action plan implemented in 2015, which show that the transition to the Circular Economy helped to put the European Union (EU) back on the path of job creation. With regard to the textile industry, the actions are aimed at improving the design for reuse and recycling of high quality packaging.

\section{Methodology}

Initially, the articles on Circular Economy applied to the textile industry were searched in the Scopus database, using as keywords: "Circular Economy" and "textil *", delimiting only in articles in all languages, published until 2020. The search was carried out in September 2020 and returned 99 articles, which were read the titles and abstracts to check if the words "Circular Economy" and "textil

*" appeared together. Of this amount, 63 articles remained. The objective was to identify the studies that conducted empirical research carried out in textile in- 
dustries and what were their purposes.

Multi-case studies are more convincing and robust. It was decided to use the multi-case study because it follows the logic of replication, unlike sampling, that is, it does not allow generalization of results for the entire population, but rather the possibility of predicting similar results (literal replication) or that of produce contrary results for predictable reasons (theoretical replication) [12].

Twenty industries are registered with the Textile Industries Union of Ceará, which are located in the metropolitan region of Fortaleza. As a research instrument, the interview was conducted, which corresponds to an important technique that allows to develop a close relationship between people [13].

Two semi-structured interviews were conducted with managers of these industries, aiming to identify their perception regarding insertion in a Circular Economy. The semi-structured interview, combines closed and open questions and the interviewee is free to position himself favorable or not on the topic, without being attached to the question asked [14].

Six guiding questions were established for the interviews, which are found in the appendix of this thesis. The questions are based on the theoretical framework on Circular Economy, presented throughout articles 1 and 2. The interviews were conducted in the months of August and September 2020 and took place remotely and over the phone.

After the interviews, the information was analyzed using the content analysis technique, which corresponds to a set of communication analysis techniques that aims to obtain indicators that allow inferring knowledge related to messages [15].

The Product Input Matrix and the Table of Resources and Uses of the State of Ceará were used to calculate the participation of the textile sector in relation to each sector. With the Tables of Resources and Uses and the Matrices of Product Input, it is possible to analyze, in detail, the production structure of Ceará and how economic activities are related within this economy, as well as the impacts that are generated on the final demand.

\section{Results}

Among the 63 articles identified, which contained in the summary the keywords: "Circular Economy" and "textil", it was observed that they dealt with topics such as innovation in the textile industry, aiming at reducing the emission of waste; empirical studies in European countries, in order to propose actions that help industries in the transition to the Circular Economy; implementation of the Circular Economy principles in industrial textile processes and the identification of how textile waste can be reused as raw material for other productive sectors.

To conduct semi-structured interviews with the managers of the textile industries in Ceará, affiliated to Sinditêxtil-CE, guiding questions were elaborated, facilitating the organization of what was sought to investigate. In August 2020, calls were made and emails were sent to the 20 industries affiliated to Sin- 
ditêxtil-CE. Of this total, 2 companies returned. The interviews took place via google meet and the other by phone.

In Table 1 presents a summary of the information obtained in a categorized

Table 1. Summarized responses to interviews with managers textile sector in Ceará.

\begin{tabular}{|c|c|}
\hline \multirow[t]{2}{*}{ Categories } & Answers \\
\hline & Firm 1 \\
\hline $\begin{array}{l}\text { Description of the national } \\
\text { classification of economic } \\
\text { activities }\end{array}$ & Preparation and spinning of cotton fibers. \\
\hline Time in the market & 40 years \\
\hline $\begin{array}{l}\text { Description of the main } \\
\text { stages of the industrial } \\
\text { process }\end{array}$ & $\begin{array}{l}\text { Mechanical transformation of fiber and yarn and } \\
\text { sale for knitting. }\end{array}$ \\
\hline Main raw materials used & Cotton and Polyester \\
\hline Origin of raw materials & $\begin{array}{l}\text { Cotton-Mato Grosso } \\
\text { Polyester-Asia }\end{array}$ \\
\hline $\begin{array}{l}\text { Destination of the finished } \\
\text { product }\end{array}$ & $\begin{array}{l}99.6 \% \text { for the domestic market, with emphasis on } \\
\text { the States of Santa Catarina, São Paulo and Rio de } \\
\text { Janeiro, }\end{array}$ \\
\hline $\begin{array}{l}\text { Manager's understanding } \\
\text { of Circular Economy }\end{array}$ & $\begin{array}{l}\text { I didn't know the term, but it related to recycling } \\
\text { and reuse of waste. }\end{array}$ \\
\hline $\begin{array}{l}\text { Strategies adopted } \\
\text { regarding recycling, reuse } \\
\text { or reuse of waste }\end{array}$ & $\begin{array}{l}\text { Waste is reused in the production chain. Those } \\
\text { that are not reused are sold to other textile } \\
\text { industries for the manufacture of carpets and } \\
\text { hammocks. } \\
\text { The company did not carry out training }\end{array}$ \\
\hline $\begin{array}{l}\text { Existence of } \\
\text { environmental legislation } \\
\text { related to the textile sector }\end{array}$ & $\begin{array}{l}\text { The industry can only sell the waste to companies } \\
\text { that follow environmental legislation, such as } \\
\text { controlled disposal and environmental licensing } \\
\text { protocols }\end{array}$ \\
\hline
\end{tabular}

Importance of Society, Government and Employees in reaching the Circular

Economy Company guides and makes employees aware of waste; For the manager, the generation of waste is a concern for all companies and employees, demonstrating the need to preserve

\section{Firm 2}

Manufacture of knitted fabrics

60 years, 27 of them in the current pole.

Transformation of the yarn into knitwear and flat fabrics. The successive stages of the process are: receipt of the thread, weaving, preparation, opener, stamping or dyeing, vaporization, raw process, review of the quality control, finishing, packaging and sending to the finished products stock.

Yarn (99\%) and raw plain fabric (1\%)

Yarn-imported from China, Indonesia and India Raw plain fabric-Sao Paulo

Domestic market: Northeast, Southeast and South regions, with predominance of the States of Ceará and Pernambuco. Sale to large womenswear stores, C \& A, Marisa and Renner.

He associated the concept with actions of sustainability, reuse and increasing the useful life of the material.

Methodology for reusing materials in the industry itself; Selective collection implemented at the factory; Training in relation to selective collection; Reuse of plastic packaging.

In compliance with the legislation of the Ceará State Environment Department (SEMACE) and the State Environmental Council (COEMA); Programs in the textile industry with less impacting chemicals; Effluent evaluation Industry evaluated by waste management. jobs. EC can be achieved by the pressure of society not to purchase imported products, from slave labor. The consumerist stance that influences companies was mentioned and they generally practice Circular Economy, as it is a matter of survival. The Government must be concerned with health and education, and not influence public policies that impact industries.

$\begin{array}{ll}\text { Main barriers and } & \text { Industries need to measure waste and waste, and } \\ \text { prospects for adopting the } & \text { people must change awareness and industries } \\ \text { Circular Economy } & \text { must be partners in the use of resources. }\end{array}$

The Government does not have policies for the Circular Economy, and there is no due inspection by companies; The Government does not have a waste management plan; Partnerships with suppliers that encourage sustainable actions;

$\mathrm{EC}$ is a trend, as many companies that do not adopt may lose market share. Adoption of used clothing collection; Elaboration of the product design, in order to produce it with less environmental impact; Technology is fundamental to reach the Circular Economy.

Source: Elaborated by the authors, 2021. 
way, in order to understand the strategies adopted by the textile industries with a focus on Circular Economy. Six guiding questions were elaborated in the semistructured interview.

As shown in Table 1, the managers interviewed did not have knowledge about the concept of Circular Economy, however they already adopt sustainable actions that are incorporated by the concept, such as reuse and reuse, corroborating with [12], who claim that Circular Economy is an integrated waste management system and should cover the subsystems that connect the transformation of raw materials into waste with the waste treatment subsystem.

IPECE provides the Resources and Uses Tables (TRUR/CE) and the Input-Product Matrix (MIPR/CE) prepared for the economy of Ceará, which detail the different levels of activities and products. The information is from the year 2017, however the data is from 2013 (most recent year in which the data were collected).

As for the relations of the textile sector with the other economic sectors, based on the input-product table of the state of Ceará, Table 2 presents the activities that have the greatest relationship with the textile sector.

The coefficients shown in Table 2 are the results of calculations that investigate the relationships between economic sectors. The higher the coefficient, the greater the level of relationship between sectors. Based on the information in Table 2, it can be seen that the textile sector in Ceará has a greater relationship with the activities of manufacturing textile products, clothing and accessories, footwear and leather goods $(0.0560)$.

The greater relationship of the textile industry with the activity of manufacturing textile products occurs due to the diversity of the production chain and the reuse of waste from one stage in subsequent stages or processes. For example: Cotton is used to make the fabric, which is transformed, by another textile industry, into a shirt.

\section{Conclusions}

By knowing the relationships existing between the economic sectors, it is possible to elaborate an agenda that aims to implement sustainable actions aimed at

Table 2. Relations between the textile sector and other economic sectors in Ceará.

\begin{tabular}{|c|c|c|c|c|c|c|}
\hline $\begin{array}{l}\text { Code } \\
\text { from } \\
\text { activity }\end{array}$ & Activities & $\begin{array}{l}0303 \text { Manufacture of } \\
\text { textile products, clothing } \\
\text { and accessories, footwear } \\
\text { and leather goods }\end{array}$ & $\begin{array}{l}0315 \text { Other } \\
\text { industrial } \\
\text { activities }\end{array}$ & $\begin{array}{l}0801 \text { Accommodation } \\
\text { services }\end{array}$ & $\begin{array}{l}1001 \text { Financial, } \\
\text { insurance and } \\
\text { related services } \\
\text { activities }\end{array}$ & $\begin{array}{l}1501 \text { Arts, culture, } \\
\text { sports and recreation } \\
\text { and other service } \\
\text { activities }\end{array}$ \\
\hline 0303 & $\begin{array}{l}\text { Manufacture of textile } \\
\text { products, clothing and } \\
\text { accessories, footwear } \\
\text { and leather goods }\end{array}$ & 0.0560 & 0.0047 & 0.0063 & 0.0031 & 0.0069 \\
\hline
\end{tabular}

Source: Elaborated by the authors, 2021. 
the Circular Economy. These actions must be planned, implemented and evaluated considering the government, society and industry actors.

With regard to the supply of inputs or products for the textile industry, it is possible to verify the relationships with other textile sectors and the use of other activities for domestic consumption, that is, necessary for the manufacture of new products, such as textile products, chemicals, electricity and transportation services.

The mapping of the route where the inputs come from, how the products are manufactured and where they are destined, assists in the planning of targeted policies, as well as actions aimed at making business circular.

As a contribution, the study presents a diagnosis of the relationships between the textile industry of the State of Ceara and other sectors, in order to enable the development of sustainable actions that encourage the reduction of environmental impacts, in addition to the assistance in the development of projects that stimulate relations between industrial sectors.

It is suggested that, for further studies, the scope of the investigation be expanded, as well as the use of other methods and the addition of other variables that affect the implementation of a Circular Economy.

\section{Conflicts of Interest}

The authors declare no conflicts of interest regarding the publication of this paper.

\section{References}

[1] Ellen MacArthur Foundation (2017) A New Textiles Economy: Redesigning Fashion's Future.

https://www.ellenmacarthurfoundation.org/assets/downloads/publications/A-NewTextiles-Economy_Full-Report.pdf

[2] United Nations Environment Programme (UNEP) (2019) Global Resources Outlook 2019: Natural Resources for the Future We Want. https://wedocs.unep.org/bitstream/handle/20.500.11822/27517/GRO_2019.pdf

[3] Sachs, I. (2002) Caminhos para o desenvolvimento sustentável. Garamond, Rio de Janeiro.

[4] Lewandowski, M. (2016) Designing the Business Models for Circular EconomyTowards the Conceptual Framework. Sustainability, 8, Article No. 43. https://doi.org/10.3390/su8010043

[5] Sauvé, S., Bernard, S. and Sloan, P. (2016) Environmental Sciences, Sustainable Development and Circular Economy: Alternative Concepts for Trans-Disciplinary Research. Environmental Development, 17, 48-56. https://doi.org/10.1016/j.envdev.2015.09.002

[6] Sehnem, S. and Pereira, S.C.F. (2019) Rumo à Economia Circular: Sinergia Existente entre as Definições Conceituais Correlatas e Apropriação para a Literatura Brasileira. Revista Eletrônica de Ciência Administrativa, 18, 35-62. https://doi.org/10.21529/RECADM.2019002

[7] Shirvanimoghaddam, K., Motamed, B., Ramakrishna, S. and Naebe, M. (2020) Death by Waste: Fashion and textile Circular Economy Case. Science of the Total 
Environment, 718, Article No. 137317. https://doi.org/10.1016/j.scitotenv.2020.137317

[8] Niinimäki, K., Peters, G., Dahlbo, H., Perry, P., Rissanen, T. and Gwilt, A. (2020) The Environmental Price of Fast Fashion. Nature Reviews Earth \& Environment, 1, 189-200. https://doi.org/10.1038/s43017-020-0039-9

[9] Febratex Group (2019).

https://fcem.com.br/noticias/quais-sao-os-principais-polos-da-industria-textil-do-b $\underline{\text { rasil }}$

[10] Trompieri, N., Cavalcante, A.L., Maia, A. C.L., Suliano, D.C., Pontes, P.A. and Paiva, W. de L. (2018) A Economia do Ceará: Uma Análise Setorial no Período 2002-2018 Palavras-chave. BNB Conjutura Econômica, 263-288.

[11] IPECE (2020) Economic Research Institute of the State of Ceará. https://www.ipece.ce.gov.br/tabela-de-recursos-e-usos-e-matriz-de-insumo-produt o-regionais-para-economia-cearense/

[12] Yin. R.K. (2001) Estudo de caso: planejamento e métodos. 2nd Edition, Bookman, Porto Alegre.

[13] Minayo, M.C.S. (2010) Técnicas de pesquisa: entrevista como técnica privilegiada de comunicação. In: O desafio do conhecimento: pesquisa qualitativa em saúde. 12. ed. São Paulo: Hucitec, 261-297.

[14] Bardin, L. (1979) Análise de conteúdo. Lisboa: Edições, 70, 1979.

[15] Cobo, S., Dominguez-ramos, A. and Irabien, A. (2017) From Linear to Circular Integrated Waste Management Systems: A Review of Methodological Approaches. Resources, Conservation \& Recycling, 135, 279-295. 